\title{
Influence of Building Material Solution of Structures to Effectiveness of Real Estate Development
}

\author{
Viera Somorová \\ Slovak University of Technology Bratislava \\ Faculty of Civil Engineering, \\ e-mail: viera.somorova@stuba.sk
}

\begin{abstract}
Real estate development is in its essence the development process characterized by a considerable dynamics. The purpose of the development process is the creation of buildings which can be either rented by future unknown users or sold in the real estate market. A first part of the paper is dedicated to the analysis of the parameters of buildings solutions considering the future operating costs in a phase of designing.

Material solution of external structures is a main factor not only in determining the future operating costs but also in achieving the subsequent economic effectiveness of the real estate development. To determine the relationship between economic efficiency criteria and determine the optimal material variant of building constructions for the specific example is the aim of the second part of paper.
\end{abstract}

Key words: development process, material solution of structures, life cycle cost, price of a lease, investments costs, operating costs, payback period of investment

\section{Introduction}

A success of the development process is given by its effectiveness. In the process of selling the criterion of effectiveness is the amount of the profit. However, if the development firm will not sell a building, but it rents it out, the requirement for the maximum effectiveness is inevitable. The effectiveness of the development process can be evaluated according to several criteria. A priority criterion of the economic effectiveness is the payback of deposited investments costs. The payback period depends on the amount of incomes during the operation of buildings which depend on the price of a lease. The main requirement of clients who rent a space of the building is to allow the price of a lease (rental price). The requirements of future clients must be respected by a development firm. A basis for establishing rental prices is the investment of a building and its operating costs. 


\section{Development process}

The development process incorporates all life-cycle stages of the building, namely: in the phase from the start of an idea applicable in the real-estate market up to financing, design and realization of the building and in the phase of the operation of the building [1].

The operation of the building is associated with operating costs. They represent a total of costs expended for the functioning of the building during its operation. They are costs of all supporting activities which enable the building to fulfill a goal for which it was realized.

Operating costs along with investment costs and the costs of liquidation constitutes the lifecycle costs (LCC) of the building.

An important stage of the life-cycle of the building, at which it is possible to influence future operating costs to a maximum, both the preparation and implementation phase is at an acquisition stage. It is possible to define as much as $50 \%$ of future operating costs already in the phase of the design process.

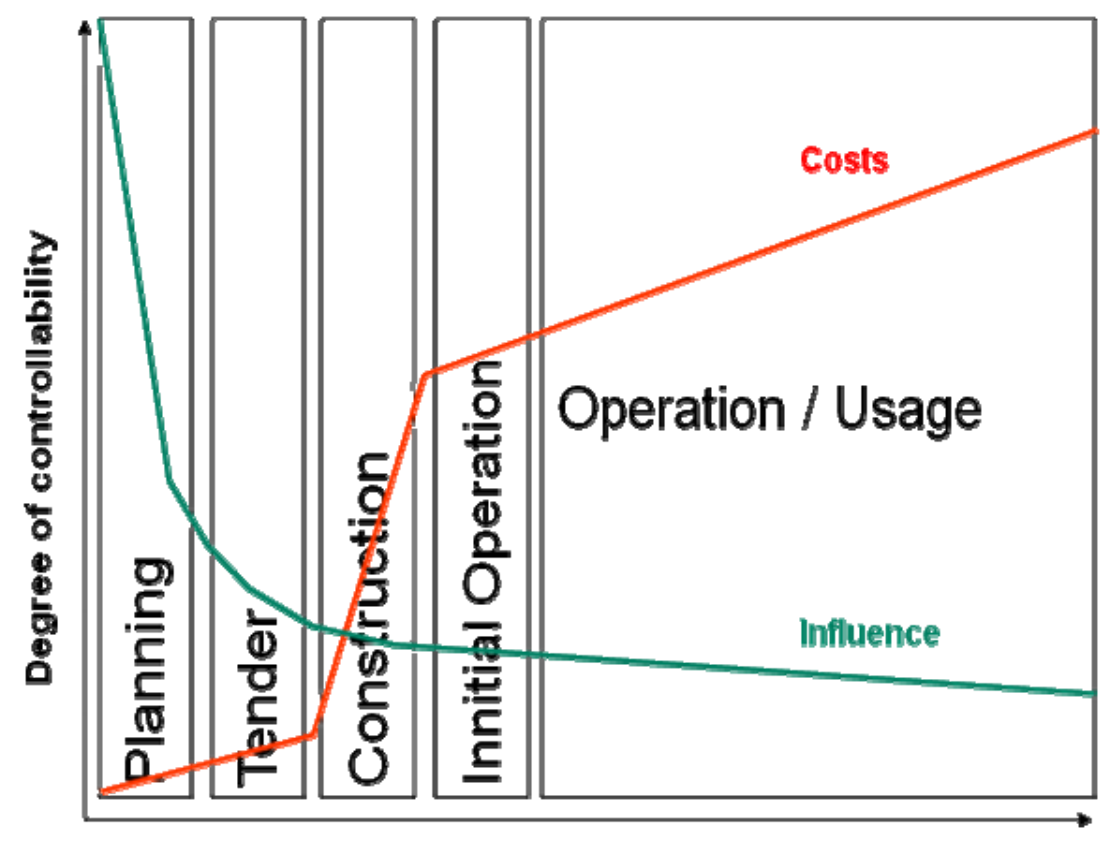

Real Estate lifecycle

Figure 1: The possibility of influencing the LCC in individual LC phases of the building [2]

This fact is confirmed also by a higher-indicated figure where exists the possibility of influencing the future operating costs in the phase of drafting the architectural, material and structural solution. 


\section{Design phase of the development process}

The objective of development process is to achieve the payback of investments and the maximum profit. This objective can be accomplished by a system co-operation between the developer and architect/designer in the phase of designing.

The future amount of operating costs is determined already in the design phase of the development process. They are dependent on the:

- developer

- $\quad$ architect / designer [3].

Developer has the main role continually throughout the development process. The development firm will define its idea of the future shape of the building on the basis of the recognition of requirements raised by future users and on the basis of its own experience gained in the previous projects. The developer coordinates a team of people in the development process.

Architect/designer has a leading position in the design process of the building. The shaping of the provider's idea into a particular form of the building is a long-term process. On the basis of many consultations with a developer the architect will elaborate some variants of solutions. The requirements of the development firm are incorporated in the architectonic solution of the building by defining disposition and space solutions.

According to the architectonic study a designer will elaborate the constructional and material solution of the building. In order to define the influence of the material and constructional solution of the building on the effectiveness of deposited investments it is necessary to define the mutual relation of the constructional and material solution of operating costs.

The building is defined at the certain time and in the certain space by its architectonic solution. The solution is a three-dimensional design of the arrangement of internal building spaces into the smoothly functioning unit with a defined shape, structure, material, colourful appearance of the building, and harmonizing space location [4].

It consists of the:

- location in a building space,

- disposition and space solution,

- structural design, material, and colourful appearance of the building and of its individual elements,

- material solution of structure,

- design of the technological equipment.

The parameters of buildings, which influence or can influence the amount of operating costs in the design are following:

- disposition and space solution,

- material solution of structures,

- technical equipment.

The above-indicated solutions have influence on the whole life-cycle of the building and also on future operating costs. 
The influence of parameters on the amount of operating costs is marked in Table 1 as " $x$ ".

Table 1: The mutual relationship between operating costs and the parameters of building [5]

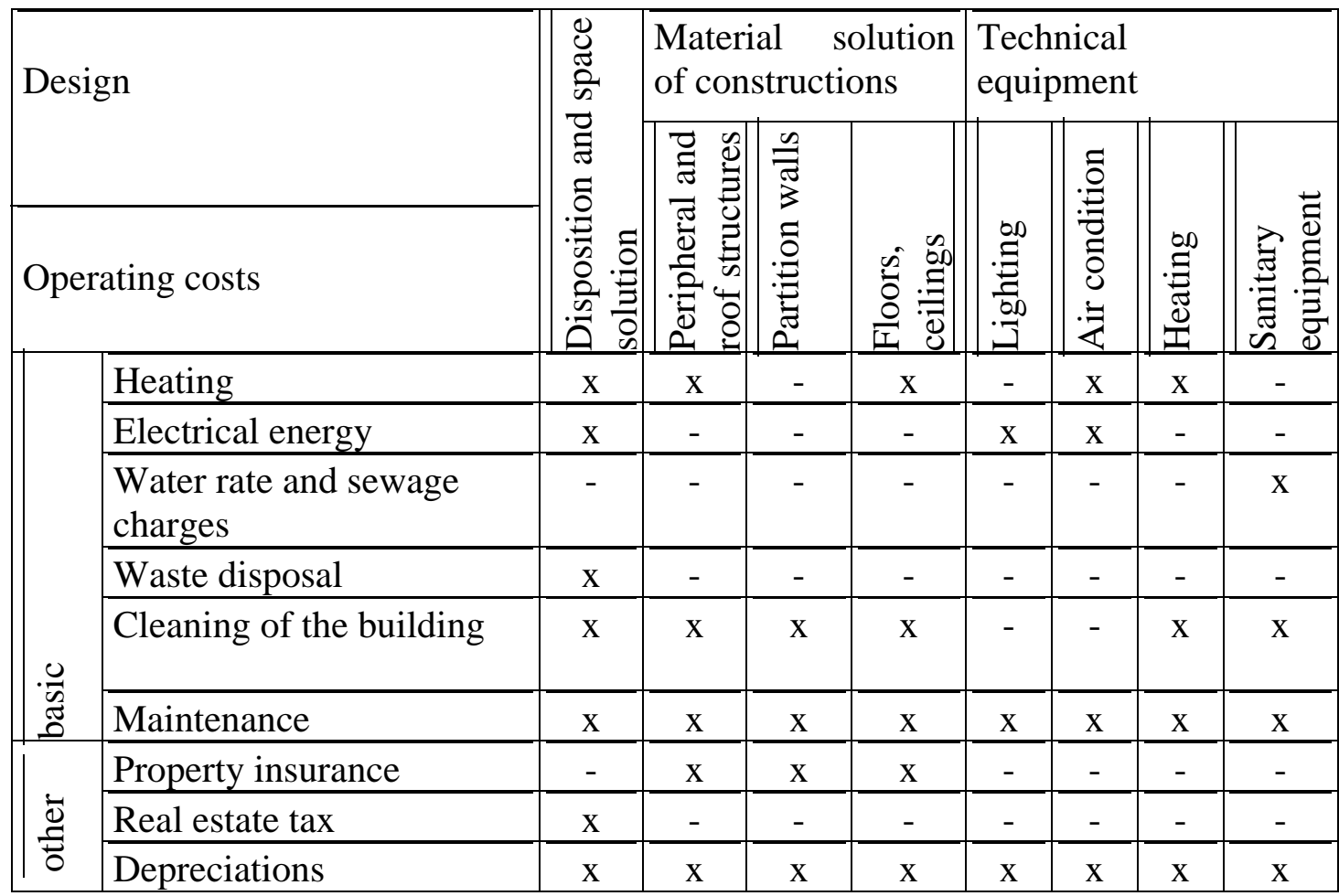

The disposition and space solution along with the material solution of building constructions have influence primarily on the basic operating costs of heating, and also on the electrical energy, cleaning of the building and on the costs associated with maintenance.

The material solution of peripheral constructions directly predetermines the future heating costs and the costs expended for their maintenance [6].

The material solution of partition walls, floors and ceilings is effective in that case when it meets the specific space requirements and when it is for a long time sustainable.

The material solution of floors: In the course of exploitation of the building almost three quarters of the costs required for cleaning represent the costs for the maintenance of floors. A careful choice of the material solution decided in the design phase enables one to avoid damages in the phase of using the building, and in the first place to bear the minimum costs for cleaning and the maintenance. The floor porosity has a great influence on the necessity of maintenance.

The material solution of walls and ceilings: A wide range of the material solution of walls and ceilings includes these categories: paint, allpaper, other natural materials (e.g. wood, cork, stone, steel and glass).

The technical equipment of the building should create the optimum solution of the comfortable internal environment. The technological equipment affects by its parameters the amount of future costs connected with its operation. 


\section{Effectiveness of the real estate development}

Economic criteria of the effective development process are following:

- payback period of applied investments which must be as short as it is possible,

- price of the rent depending on the amount of operating costs and net yields - CF,

- life-time costs of the building (LCC).

1. Payback period of applied investments

The payback of investment is the space of time, in which revenues are equal to the value of expended investment costs. The revenues represent net yields - cash flow (CF) equal to yields (price of the lease) minus costs (operating costs). In addition, the payback period is demonstrated in the following formulae:

$$
\begin{gathered}
\mathrm{PP}=\mathrm{CINV}: \sum_{\mathrm{t}=0}^{\mathrm{t}=\mathrm{pp}} \mathrm{CF} \cdot(1+\mathrm{u})^{\mathrm{pp}} \\
\mathrm{CF}=\mathrm{R}-\mathrm{COP}
\end{gathered}
$$

where:

CINV = investment costs $(€)$

$\mathrm{CF}=$ cash flow $(€)$

$\mathrm{COP}=$ operating costs $(€)$

$\mathrm{R}=$ revenue $(€)$ = price of the lease

$\mathrm{t}=$ time (year)

$\mathrm{PP}=$ payback period

$\mathrm{u}=$ interest rate in absolute terms

2. Price of the lease

It is determined in relation to net yields (CF) and operating costs. It is quoted as a price of the lease per $1 \mathrm{~m}^{2}$ of the floor area which is leased.

$$
\mathrm{CF}=\mathrm{COP}+\mathrm{CF}
$$

\section{Life cycle costs (LCC)}

Life cycle costs of the building (LCC) are calculated as a total of the investment costs with the amount of operating costs of the building during all its life-time being adjusted by an interest rate.

$$
\mathrm{LCC}=\mathrm{CINV}+\sum_{t=0}^{t=T} \mathrm{COP} \cdot(1+\mathrm{u})^{\mathrm{T}}
$$

where:

$\mathrm{CINV}=$ investment costs

COP = operating costs

$\mathrm{u}=$ interest rate in absolute terms 
$\mathrm{t}=$ operating time of the building

$\mathrm{T}=$ lifetime of the building

Requirements for the economic effectiveness of the real estate development is:

$$
\mathrm{PP}=\mathrm{CINV}: \sum_{t=0}^{t=p p} \mathrm{CF} \cdot(1+\mathrm{u})^{\mathrm{pp}}=\mathbf{m i n}
$$

Condition for obtaining a PP is:

$$
\begin{gathered}
\mathrm{CF}=\mathrm{R}-\mathrm{COP}=\mathbf{m a x} \\
\mathrm{COP}=\mathbf{m i n}
\end{gathered}
$$

\section{Determination of the optimum variant of the material solution of building constructions from the aspect of effectiveness of the real estate development}

Requirements for the economic effectiveness of the development process are to achieve the optimum price of a lease considered from the aspect of the requested economic return of deposited investments and the optimum variant considered from the aspect of LCC. The architect/designer will elaborate the variants of the material solutions of building constructions.

It is necessary to continually analyze the impact of individual variants of the material solution of building constructions realized in the design phase.

The analysis should be done from the aspect of the investment costs of buildings not only comprehensively but also from the aspect of future operating costs. (It is assumed that other acquisition costs are constant in the given time for all variants.)

The costs expended on any material of the building (for example, on solving the proposed material for a peripheral construction) in the phase of designing and the costs expended on the operation in the phase of its using are compared to different material variants of building structures.

\section{Analysis of variants of material building construction}

A procedure for the determination of the optimum variant of the material solution of constructions of the building for a specific example is as follows:

We shall take into account the individual variants of proposals for a building on a basis of the material solution of constructions, such as variants of $V_{1}, V_{2}, \ldots, V_{j}, \ldots, V_{n}$.

The priority position is attributed in relation to operating maintenance costs to the material solution of peripheral constructions. It directly predetermines the future heating costs and the costs expended for their maintenance. 
The highest percentage share of the total operating costs is formed by heating costs- ca $65 \%$. From among the above-indicated solutions involving the disposition and space solution as well as the material solution of peripheral constructions it is just the latter solution which has a great influence on the amount of heating costs.

In order to ensure the failure-free operation of buildings it is inevitable to take care of their maintenance. The maintenance costs of building constructions are dependent on a choice of the material solution of constructions.

The influence of the material solution of peripheral constructions, which is exerted on criteria of the economic effectiveness requested in the development process, will be analyzed for the following two variant:

$\mathrm{V}_{1}$ - whole-glazed peripheral construction

$\mathrm{V}_{2}$ - masonry POROTHERM

Compounds: internal plaster Porotherm Universal

$10 \mathrm{~mm}$

moulded bricks Porotherm 44P+D (440x250x238 mm) $440 \mathrm{~mm}$

external thermal-insulation plaster Porotherm TO 490 mm

Input data:

- width of the building

$10 \mathrm{~m}$

- length of the building

$20 \mathrm{~m}$

- height of the building

- area of the peripheral construction $V_{1}$

$18 \mathrm{~m}$

- area of the peripheral construction $V_{2}$

$1080 \mathrm{~m}^{2}$

$756 \mathrm{~m}^{2}$ (= area of the peripheral

- floor area of the building (FA) for $\mathrm{V}_{1}$ a $\mathrm{V}_{2}$

$-\mathrm{u}=$ interest rate in absolute terms

construction minus 30\% for openings)

$1200 \mathrm{~m}^{2}$

$1,5 \%$

The priority position among criteria of the economic effectiveness of the development process is the price of a lease. The economic return of investment costs depends on the cash flow which gives rise, together with operating costs, to the price of a lease.

The amount of the price of a lease is influenced by:

- investment costs which have the main influence on the economic return. From the requested economic return the amount of the cash flow constituting a part of the price of a lease is calculated. .

- operating costs of the building which are paid by clients renting out a space of the building.

\section{a) Investment costs}

The investment costs CINVi will be specified for individual variants. A survey of indicators of the investment costs and the total building costs of peripheral construction variants are shown in Tab.1: 
Table 2: Investment costs

\begin{tabular}{|c|l|c|}
\hline Variants & $\begin{array}{l}\mathrm{CINV}_{\mathrm{i}} \\
\left(€ / \mathrm{m}^{2}\right)\end{array}$ & $\begin{array}{c}\mathrm{CINV}_{\mathrm{i}} \\
(€ / \text { building })\end{array}$ \\
\hline $\mathrm{V}_{1}$ & 250 & 270000 \\
\hline $\mathrm{V}_{2}$ & 101.51 & 76742 \\
\hline
\end{tabular}

Note: $\mathrm{CINV}_{\mathrm{i}}$ investment costs for the $1 \mathrm{~m}^{2}$ area of the peripheral construction

\section{b) Operating costs}

For the analysis were chosen the operating costs of heating and maintenance which have a crucial influence on the total operating costs.

The operating costs of heating are determined according to the annual consumption (involved in the project documentation) and the unit price per $1 \mathrm{~m}^{3}$ for gas.

The operating costs of maintenance are stipulated for individual variants according to the mode of maintenance depending on the material solution of the peripheral construction.

The mode of maintenance and its costs include:

$-\mathrm{V}_{1}$ : the maintenance of the whole-glazed peripheral construction demanding the necessity of washing the construction two times. The costs of one washing are 0.45 Euros $/ 1 \mathrm{~m}^{2}$,

$-\mathrm{V}_{2}$ : the maintenance of the peripheral construction POROTHERM depends on the lifetime of the external plaster which corresponds to ca 20 years. After this period it is necessary to remove the plaster from the peripheral construction and to spread a new plaster. According to the Price List of works the costs of the new plaster amount to 16,653 Euro/ $1 \mathrm{~m}^{2}$. A survey of the operating costs is indicated in Table 2.

Table 3: Operating costs - indicators

\begin{tabular}{|l|c|c|c|}
\hline \multirow{2}{*}{ variants } & \multicolumn{2}{|c|}{$\mathrm{COP}_{\mathrm{h}}$ - heating } & $\begin{array}{c}\mathrm{COP}_{\mathrm{m}}- \\
\text { maintenance }\end{array}$ \\
\cline { 2 - 4 } & $\mathrm{m}^{3} / 1 \mathrm{~m}^{2} /$ year & $\left(€ / 1 \mathrm{~m}^{2} /\right.$ year $)$ & $\left(€ / 1 \mathrm{~m}^{2} /\right.$ year $)$ \\
\hline $\mathrm{V}_{1}$ & 14.47 & 7.27 & 0.90 \\
\hline $\mathrm{V} 2$ & 4.566 & 2.356 & $16.653^{1}$ \\
\hline
\end{tabular}

Note: Operating costs are specified for:

- gas consumption $\left(\mathrm{m}^{3}\right)$ per $1 \mathrm{~m}^{2}$ of the floor area $(\mathrm{COPh}=$ costs of heating)

- maintenance per $1 \mathrm{~m}^{2}$ of the peripheral construction area (COPm = costs of maintenance).

\section{c) Determination of $\mathbf{C F}$}

The lifetime of the peripheral construction corresponds approximately to 20 years when $\mathrm{T}=$ 20. Suppose that the lifetime of the peripheral construction is equal to the payback period of investment costs. Then the aim of the analysis is to determine at a given time return CF and operating costs as a basis for determining the rental price per square meter of floor area / $\mathrm{m} 2$ /

\footnotetext{
${ }^{1}$ Costs of the maintenance in the 20th year of the lifetime of the peripheral construction.
} 
month). Then the aim of the analysis is to is aimed to determine the CF and operating costs as a basis for the calculation of the price of a lease per $1 \mathrm{~m}^{2}$ of the floor area/ $1 \mathrm{~m}^{2} / \mathrm{month}$ ).

For variants of $\mathrm{V}_{1}$ and $\mathrm{V}_{2}$ are computed operating costs for the period of 20 years where $\mathrm{u}=$ interest rate in absolute terms $=0,015$ shown in the below-indicated formula:

$$
\sum_{t=0}^{t=20} \mathrm{COP} \cdot(1+0.015)^{20}
$$

The calculation of $\mathrm{C}_{\mathrm{hi}}$ for a period of 20 years is computed for $\mathrm{V}_{1}$ and $\mathrm{V}_{2}$ in the following way:

$\mathrm{V}_{1} \quad \mathrm{COP}_{\mathrm{h} 1}=7.27 \times 1200 \times 20 \times(1+0,015)^{20}=235025 €$

$\mathrm{V}_{2} \quad \mathrm{COP}_{\mathrm{h} 2}=2.356 \times 1200 \times 20 \times(1+0,015)^{20}=76165 €$

The calculation of $\mathrm{C}_{\mathrm{mi}}$ for a period of 20 years is computed for $\mathrm{V}_{1}$ and $\mathrm{V}_{2}$ in the following way:

$\mathrm{V}_{1} \quad \mathrm{COP}_{\mathrm{m} 1}=0,90 \times 1080 \times 20 \times(1+0,015)^{20}=20186 €$

$\mathrm{V}_{2} \quad \mathrm{COP}_{\mathrm{m} 2}=16.653 \times 756 \times(1+0,015)^{20}=16958 €+536 €=^{\prime} 17394 €$

Notice: washing windows -2 times a year $=324 \times 1,00 \times(1+0,015)^{20}=536 €$

Table 4: A survey of COPi for individual variants of the building

\begin{tabular}{|l|c|c|}
\hline & $\begin{array}{c}\mathrm{V}_{1} \\
{[€]}\end{array}$ & $\begin{array}{c}\mathrm{V}_{2} \\
{[€]}\end{array}$ \\
\hline $\mathrm{COP}_{\mathrm{hi}}$ & 235025 & 76165 \\
\hline $\mathrm{COP}_{\mathrm{mi}}$ & 20186 & 17394 \\
\hline$\sum_{t=0}^{t=20} \mathrm{COP} .(1+\mathrm{u})^{20}$ & 255211 & 93559 \\
\hline
\end{tabular}

(Note: To determine the average annual operating costs the time of the value of money is calculated.)

$\mathrm{CF}$ is calculated from the formula (1)

$$
\mathrm{PP}=\mathrm{CINV}: \sum_{\mathrm{t}=0}^{\mathrm{t}=\mathrm{pp}} \mathrm{CF} \cdot(1+\mathrm{u})^{\mathrm{pp}}
$$

$\mathbf{C F}_{\mathbf{1}}$ (for the variant of $\mathrm{V}_{1}$ ):

$$
20=270000:: \sum_{t=0}^{t=20} \mathrm{CF} \cdot(1+0.015)^{20}
$$

$\mathrm{CF}_{1}=[270000: 20]: 1.015^{20}=10022 € / \mathrm{m}^{2} \mathrm{FA}_{\text {building }} /$ year

$\mathrm{CF}_{1}=10022: 1200: 12=\mathbf{0 , 7 2} € / \mathrm{m}^{2} \mathrm{FA} /$ month 
$\mathbf{C F}_{2}$ (for the variant of $\mathrm{V}_{2}$ ):

$$
20=76742: \sum_{t=0}^{t=20} \mathrm{CF} \cdot(1+0.015)^{20}
$$

$\mathrm{CF}_{2}=[76742: 20]: 1,015^{20}=2848 € / \mathrm{m}^{2} \mathrm{FA}_{\text {building }} /$ year

$\mathrm{CF}_{2}=2848: 1200: 12=\mathbf{0 , 2 0} € / \mathrm{m}^{2} \mathrm{FA} /$ month

Note: In practice, the price of a lease is determined per $1 \mathrm{~m}^{2} \mathrm{FA} / \mathrm{month}$.

\section{d) Price of the lease}

The price of a lease is calculated from the formula as follows:

$$
\mathrm{R}_{\mathrm{i}}=\mathrm{COP}_{\mathrm{i}}+\mathrm{CF}_{\mathrm{i}}
$$

For variants $\mathrm{V}_{1}$ a $\mathrm{V}_{2}$ the amount of annual operating costs is quoted after recounting to $1 \mathrm{~m}^{2}$ $\mathrm{FA} /$ year $\left(\mathrm{COP}_{\mathrm{i}}\right)$ :

$\mathrm{COP}_{1}: \mathrm{FA}:(1+\mathrm{u})^{20}=255211: 1,015^{20}: 12=\mathbf{1 3}, \mathbf{1 6} € / \mathrm{m}^{2} \mathrm{FA} / \mathrm{month}$

$\mathrm{COP}_{2}: \mathrm{FA}:(1+\mathrm{u})^{20}=93559: 1200: 1,015^{20}: 12=\mathbf{4 , 8 2} € / \mathrm{m}^{2} \mathrm{FA} / \mathrm{month}$

The price of a lease of the building $\left(\mathrm{R}_{\mathrm{i}}\right)$ is indicated for individual variants in Table 4:

Table 5: The price of a lease for individual variants

\begin{tabular}{|c|c|c|c|}
\hline variants & $\begin{array}{c}\mathrm{CF}_{\mathrm{i}} \\
€ / \mathrm{m}^{2} \mathrm{FA} / \mathrm{month}\end{array}$ & $\begin{array}{c}\mathrm{COP}_{\mathrm{i}} \\
€ / \mathrm{m}^{2} \mathrm{FA} / \mathrm{month}\end{array}$ & $\begin{array}{c}\mathrm{R}_{\mathrm{i}} \\
€ / \mathrm{m}^{2} \mathrm{FA} / \mathrm{month}\end{array}$ \\
\hline $\mathrm{V}_{1}$ & 0,72 & 13,16 & 13,88 \\
\hline $\mathrm{V}_{2}$ & 0,20 & 4.82 & 5,02 \\
\hline
\end{tabular}

Result : From the table it follows that the price of a lease is lower for variant $V_{2}$.

\section{e) Life cycle costs}

The LCC for individual variants is calculated according to the below-indicated formula[1]:

$$
\mathrm{LCC}=\mathrm{CINV}+\sum_{t=0}^{t=T} \mathrm{COP} .(1+\mathrm{u})^{\mathrm{T}}
$$

The lifetime of the peripheral construction corresponds approximately to 20 years when $\mathrm{T}=$ $20, \mathrm{u}=$ interest rate in absolute terms $=0,015$. 
Table 6: A survey of the LCC for individual variants

\begin{tabular}{|c|c|c|c|}
\hline variants & $\begin{array}{c}\mathrm{CINV}_{\mathrm{i}} \\
(€ / \text { building })\end{array}$ & $\sum_{t=0}^{t=20} \mathrm{COP} \cdot(1+\mathrm{u})^{20}$ & $\begin{array}{c}\text { LCC }_{\mathrm{i}} \\
(€ / \text { building })\end{array}$ \\
\hline $\mathrm{V}_{1}$ & 270000 & 255211 & 525211 \\
\hline $\mathrm{V}_{2}$ & 76742 & 93559 & 170301 \\
\hline
\end{tabular}

From the above-indicated table it follows that

$$
\mathrm{LCC}_{2}<\mathrm{LCC}_{1}
$$

\section{Result of the analysis: The price of a lease and the life cycle costs are lower for the variant $\mathrm{V}_{2}$.}

From our practical example it is possible to conclude that the variant $\mathrm{V}_{2}$ has the lower price of a lease than the life cycle (LCC) costs in the case of the variant $\mathrm{V}_{1}$. It follows that the required economic return during 20 years results in the lower price of a lease, which means that for a development firm the $V_{2}$ is the optimum variant considered from the aspect of the economic return of investment put in the real estate development.

The incorrect choice of constructions discussed in the paper has been proved, for example, by the fact that nowadays there exists a trend to use all-glass circumferential constructions. The costs expended for their realization are in comparison to brick or reinforced circumferential constructions higher and the operating costs expended for their maintenance in the application phase are higher as well. This fact should reflect in the choice of the material solution, in the approach to a building design and, of course, in planning the future operating maintenance costs.

\section{Conclusion}

The minimization of the payback period depends on the maximization of the cash flow obtained from a lease of the building. An important criterion of the effective development process is the optimum price of a lease, i.e. the price which complies with the client's willingness to pay it. The price of a lease depends on the occupancy rate of the building.

Costs expended on some material of the building (for example, in the solution of the proposed material for a peripheral construction) in the phase of designing and costs expended on its operation during the phase of using are compared with the initially proposed costs. A choice of the suitable parameters such as: disposition and space solution, material solution of constructions and suitable technical equipment already in the phase of designing has a direct influence on their future operating costs, which have a directly influence on the price of a lease, an important criterion of effectiveness of real estate development.

\section{References}

[1] Miles, M.E., Berens, G., Weiss, M.A. (2000). Real Estate Development. Urban Land, Institute, Washington, pp.17-21. 
[2] First facility - lecture Facility Management Consulting and Sustainable Construction. (Green Building).

[3] Somorová, V. (2004). What are Risks of the Development Process. EUROSTAV. Vol.10, No2. pp.30.

[4] Somora, B. (2002). How to Start. Bratislava, pp.25-26.

[5] Trávnik, I. (2002). Evaluation of the Economic Effectiveness of Public Works. STU, Bratislava, pp.100.

[6] Vranay, F.; Vranayová, Z.; Ocipova, D. (2010). Green energy and indoor technologies for smart buildings, Book Editor(s): Ghafoori, N. CHALLENGES, OPPORTUNITIES AND

SOLUTIONS IN STRUCTURAL ENGINEERING AND CONSTRUCTION pp 869-872 